\title{
Are Institutional Investors Beneficial to Family Firm Performance? Evidence from the French Stock Exchange
}

\author{
Olivier Colot $^{1} \&$ Jonathan Bauweraerts ${ }^{1}$ \\ ${ }^{1}$ Warocqué School of Business and Economics, University of Mons, Belgium \\ Correspondence: Olivier Colot, Professor, Warocqué School of Business and Economics, University of Mons, \\ Belgium.
}

Received: December 17, 2015

Accepted: January 19, 2016

Online Published: March 8, 2016

doi:10.5430/ijfr.v7n2p39

URL: http://dx.doi.org/10.5430/ijfr.v7n2p39

\begin{abstract}
In the context of listed family firms, prior research pointed out that agency problems between majority family owners and minority shareholders are the most prevalent in European countries where shareholders' protection is weak. This study aims at analysing how the presence of different types of institutional investors alleviates or enhances this form of agency problem. Examining the French stock market (SBF120) over the period 2002-2011, our results indicate that having a family as the first shareholder hampers financial performance. Our findings also reveal that having an institutional investor as second blockholder can be beneficial or detrimental to firm performance. Considering the distinctive nature of institutional investors, this research shows that the combination of a family as the first shareholder and a pressure-insensitive institutional investor as second blockholder exerts a positive influence on firm performance while a negative effect is found when the institutional investor is pressure-sensitive. These results confirm that the nature and the distribution of ownership is particularly important when analysing agency problems in listed firms.
\end{abstract}

Keywords: family firms, blockholders, institutional investors, performance, agency theory

\section{Introduction}

Nowadays, family firms represent a pillar of the global economic and the social fabric (IFERA, 2003; Family Business Network International, 2008). For instance, in the United States, one third of the firms listed on the S\&P500 are family firms (Anderson \& Reeb, 2003). This proportion is higher outside Anglo-Saxon countries where the protection of minority shareholders is weak (La Porta, Lopez-De-Silanes \& Shleifer, 1999). In that sense, Faccio and Lang (2002) reported that 44 percent of listed firms present a family character in Western Europe. According to the Family Business Network International (2008), family firms account for 60-85 percent of all organisations on the European continent. Given their considerable presence worldwide, family firms are expected to be increasingly targeted by external investors. For this reason, additional insights on the relationship between various types of second blockholders and family firm performance should be valuable.

Prior research revealed that it is not uncommon that external shareholders holds a large stake in listed family firms (Faccio \& Lang, 2002; Pindado, Requejo \& de la Torre, 2012; Sacristán-Navarro, Gómez-Ansón \& Cabeza-García, 2011a). For instance, Laeven and Levine (2008) claimed that more than $40 \%$ of the public firms in Western economies are characterized by the presence of one large shareholder and an additional blockholder (or more than one) who own more than $10 \%$ of the firms' shares. This situation is particularly interesting since large shareholders often display different goals and aspirations in comparison to family owners, act as stewards or rent-seekers, thereby enhancing or reducing the advantages and/or disadvantages of family ownership. Conscious of this ambivalence, researchers have investigated how the presence of large nonfamily shareholders affect value creation in listed family firms (Maury \& Pajuste, 2005; Sacristán-Navarro, Gómez-Ansón \& Cabeza-García, 2011b, 2013).

However, fewer studies have stressed the importance of considering the nature of large shareholders when analyzing family firm performance. One exception is the work of Sacristán-Navarro et al. (2011b) who found that the shareholders' combination of families and other types of investors does not significantly affect firm value. Accordingly, it is not surprising that little is known on how various types of large institutional shareholders interact with family owners to create or destroy financial value (Croci, Gonenc \& Ozkan, 2012). Exploring this issue remains important since institutional investors represent a dominant force in financial markets (Bennett, Sias \& Starks, 2003), 
especially in publicly-traded family firms (Fernando, Schneible \& Suh, 2014). This article aims to add empirical evidence in this strand of literature by analyzing how the presence of different types of institutional investors affects value creation in listed family firms. More specifically, following Brickley, Lease and Smith's (1988) classification, our study proposes to distinguish between the effect of pressure-sensitive and pressure-insensitive institutional investors on family firm performance. By so doing, we shed new light on the performance implications of institutional ownership in the family business context.

To build our theoretical arguments, we draw upon agency literature on principal-principal conflicts in family firms (Villalonga \& Amit, 2006). Agency theory suggests that the expropriation of minority shareholders by large family owners is the most prominent form of agency problems in countries with poor legal protection (Jara-Bertin, López-Iturriaga \& López-de-Foronda, 2008; Young, Peng, Ahlstrom, Bruton \& Jiang, 2008). The presence of a large second blockholder can alleviate this issue since such shareholders have the incentive and power to contest the family hegemony (Pindado et al., 2012; Sacristán-Navarro et al., 2011b). We use these theoretical foundations to develop and test our hypotheses on a sample of nonfinancial firms listed on the French stock market (SBF120) over the period 2002-2011. Taking into account that France is a French civil law country with moderated levels of investor protection (Dahya, Dimitrov \& McConnell, 2008) and that agency problems between family and nonfamily shareholders are very common in this institutional setting (Charlier \& Lambert, 2013), we argue that the presence of a family as first shareholder is detrimental to family firm performance since it will be easier for family owners to expropriate wealth from minority shareholders. We also propose that the presence of an institutional shareholder as second blockholder can reinforce or mitigate these agency problems depending on the nature of institutional ownership. Especially, pressure-insensitive institutional investors are claimed to be beneficial to family firm performance while the opposite is suggested for pressure-sensitive institutional investors.

This article contributes to the existing literature on family firms in several ways. First, we provide new empirical evidence about the performance implications of the combination of multiple large shareholders in the context of family business, a topic that has been largely overlooked so far (Pindado, Requejo, \& de la Torre, 2014). While prior research has mainly focused on the nature and the effect of the family as the largest shareholder, this study explores how different types of large shareholders interact with each other to enhance or hamper family firm performance. Second, this study investigates the role of various types of institutional investors as second largest shareholders. Although numerous scholars have argued and showed that high-quality monitoring by institutional investors enhances corporate performance (McConnell \& Servaes, 1990; Cornett, Marcus, Saunders \& Tehranian, 2007), we offer new insights on the combination of large family shareholders and pressure-sensitive or insensitive institutional investors, little being known on this problematic in the context of family firms (Croci et al., 2012). Third, in order to avoid methodological issues concerning firm unobservable heterogeneity and ownership endogeneity, we compare the results obtained with different statistical methods.

This paper is structured as follows. In a first section, we review the existing literature and develop our hypotheses. Subsequently, we present the data and the methodology used to test our hypotheses. Thereafter, we propose our results and discuss the implications of this research, as well as some limitations and suggestions for future research.

\section{Theoretical Background and Hypotheses Development}

Since the Modern Corporation described by Berle and Means (1932), numerous studies have investigated the agency relationship between principals and agents in different contexts. Basically, it is assumed that ownership dispersion enhances the extraction of private benefits by managers because small shareholders lack incentives to monitor them (Jensen \& Meckling, 1976). Villalonga and Amit (2006) refer to as "agency problem I". In contrast, the agency problem between owner and manager is mitigated in the presence of a large shareholder as he/she has greater incentives to engage in monitoring activities (Shleifer \& Vishny, 1986; 1997). Consistent with that view, it is widely accepted that the presence of a large family shareholder alleviates agency problems I as the under-diversification of her/his wealth give her/him a strong incentive to effectively monitor managers (Fama \& Jensen, 1983). Moreover, as family members are often involved in both ownership and management (Anderson \& Reeb, 2003; Villalonga \& Amit, 2006; Sraer \& Thesmar, 2007), the alignment of principal-agent goals (Jensen \& Meckling, 1976) combined with high trust and shared values among family members (Ensley \& Person, 2005) makes agency problem I less prevalent in family firms. In that sense, prior studies have shown that the monitoring role of large family owners enhances performance and alleviates conflicts between shareholders and managers (McConaughy, Walker, Henderson \& Mishra, 1998; Anderson \& Reeb, 2003; Pindado, Requejo \& de la Torre, 2008).

However, another type of agency problem can be experienced by family firms and arises from the conflict between majority and minority shareholders. In this regard, Villalonga and Amit (2006) indicate that an "agency problem II" 
occurs when the largest shareholder may use its controlling position to extract private benefits at the expense of minority shareholders. In the context of family firms, Jara-Bertin et al. (2008, p.147) claim that "family core shareholders may press managers to look out for their interests even though such actions may be detrimental to the interests of other shareholders". Their results confirm this assumption since they found that the absence of contestability of family control favours the expropriation of minority shareholders. In the same vein, Villalonga and Amit (2006) showed that the conflict between family and nonfamily shareholders in descendant-CEO firms is more costly than the owner-manager conflict in nonfamily firms. Additionally, Pindado et al. (2012) reported that listed family firms in the Eurozone distribute a higher proportion of their earnings as dividends to mitigate "agency problems II". These examples clearly illustrate that "agency problem II" can represent a major issue in listed family firms, which has been shown to be detrimental to family firm performance (Maury, 2006; Villalonga \& Amit, 2006).

Moreover, scholars claim that agency problems II are more likely to emerge in institutional contexts characterized by poor legal protection for minority shareholders (Young et al., 2008). Indeed, prior research has established that conflicts of interests between majority and minority shareholders are more important in firms operating outside Anglo-Saxon countries (Cronqvist \& Nilsson, 2003) where the lower degree of shareholders' protection facilitates the expropriation of minority investors (La Porta et al., 1999; Dahya et al., 2008). For these reasons, it can be argued that the larger the stake of family shareholders, the greater the likelihood of opportunistic and self-serving behaviours from family owners in countries where legal protection is weak (Maury, 2006). In this study, we focus on the French stock market, an institutional setting characterized by a lower degree of protection of minority shareholders in Western Europe (La Porta et al., 1999; Dahya et al., 2008). This context has been shown to represent a fertile field for the emergence of agency conflicts between majority and minority shareholders in family firms (Charlier \& Lambert, 2013). Therefore, we expect that the presence of a family as first shareholder will induce intense "agency problems II" that overshadow the benefits of the potential alignment of interests between family owners-managers (Villalonga \& Amit, 2006). For these reasons, we suggest:

\section{H1: The presence of a family as first shareholder will negatively affect financial performance.}

However, the relationship between family ownership and performance can be influenced by various contingencies that must be explored to obtain a more fine-grained analysis of family firm performance (Aguilera \& Crespí-Cladera, 2012). In listed family firms, an important contingency factor that may affect this relationship is the presence of other large shareholders in the ownership structure. In that sense, Maury and Pajuste (2005) found that Finnish family firms are more valuable when they are not monitored by other large shareholders. Jara-Bertín et al. (2008) reported that contestability of the control of the largest shareholder exerts a positive influence on value creation in listed family firms. More recently, Sacristán-Navarro et al. (2015) showed that the market value of family firms is positively affected by the presence of other large shareholders provided that the family retains control by holding most of the voting rights.

Although these studies advance our knowledge on how firms differ in terms of financial performance in the family business field, they have neglected to take into account the heterogeneity in the nature of large nonfamily shareholders. Yet, this factor is as important as the distribution of shares among shareholders when analyzing the performance implications of the ownership structure (Pedersen \& Thomsen, 2003). Indeed, while the nature of shareholders determines their goals and preferences, the proportion of shares they hold delineates their power and incentives. Considering both the identity of shareholders and the amount of shares they hold, Sacristán-Navarro et al. (2011b) revealed that the shareholder's combination of families and various types of second blockholders do not lead to increased performance on the Spanish stock market. Following this line of research, we now turn onto the consequences of having institutional investors as second blockholders in listed family firms, a topic that has been overlooked by Sacristán-Navarro et al. (2011b) owing to the lower proportion of institutional shareholding in Spain (Mínguez-Vera \& Martín-Ugedo, 2007).

Institutional investors are financial entities with substantial amounts to invest, such as insurance companies, mutual funds, pension funds, investment banks, and endowment funds. These investors have become unavoidable on the financial markets, owning more than 50 percent equity ownership and exerting a strong influence on the determination of stock prices (Bennett et al., 2003). This is also true in the context of family firms in which they possess more than the majority of equity ownership on the S\&P 500 (Fernando et al., 2014). In France, institutional investors have induced drastic changes in the functioning of French capitalism by becoming increasingly involved in the ownership structure of most companies listed on the stock exchange in the nineties (Goyer, 2006; Aglietta, 2008). Thus, France represents an appropriate national setting to explore the role of institutional investors in the value creation process of listed family firms. 
Prior research has mainly focused on the role of institutional investors as corporate monitors. Basically, due to their larger stake in the company, institutional investors have a strong incentive to monitor majority shareholders and to protect itself from the excess use of power by majority shareholders (Shleifer \& Vishny, 1997; Maury \& Pajuste, 2005; Jara-Bertin et al., 2008). Large institutional investors can act as effective monitors since they have the opportunity, resources, and ability to monitor, discipline, and influence managers, so that their involvement in corporate monitoring makes managers more focused on firm objectives than on their own goals (Shleifer \& Vishny, 1986; McConnell \& Servaes, 1990; Smith, 1996; Cornett et al., 2007). For instance, Bushee (1998) found that institutional ownership inhibits managers from engaging in earnings manipulation through cutting R\&D expenses. More practically, Richard Grasso, the CEO of New York Stock Exchange from 1995 to 2003, was forced to resign because of the pressure of institutional investors which were convinced that his compensation package was excessive (Kelly, Craig \& Dugan., 2003). Other empirical research has emphasized the monitoring role of institutional investors by showing a positive relationship between institutional ownership and corporate performance (McConnell \& Servaes, 1990; Del Guercio \& Hawkins, 1999; Cornett et al., 2007).

In the context of listed family firms, few studies have considered monitoring by institutional investors as an important corporate governance mechanism. This observation is quite surprising since family firms can benefit from the involvement of these investors with a strategic stake in the company to contest family control and reduce minority shareholder expropriation (Sacristan-Navarro et al., 2011b). In that sense, Croci et al. (2012) showed that institutional shareholders should be sensitive to the long-term components of CEO compensation packages in family firms (e.g., stock options or stock grant) because they would reinforce the ownership rights of the controlling family and thus increase the risk of family CEO entrenchment. Additionally, Gomez-Mejia, Hoskisson, Makri, Sirmon \& Campbell (2011) found that increasing institutional ownership weakens the negative relationship between family ownership and R\&D investments, thereby suggesting that family shareholders are less likely to extract private benefits at the expense of innovation expenditures in the presence of large institutional shareholders.

These examples seem to indicate that institutional ownership may improve corporate monitoring and alleviate agency problems between minority and majority shareholders in listed family firms. This could be an undeniable asset to counterbalance the disadvantages of agency problems II which are frequently observed in French family firms (Charlier \& Lambert, 2013). However, several studies pointed out that institutional investors represent a group of heterogeneous shareholders that must be investigated separately to understand the performance implications of institutional ownership (e.g. Pound, 1988; Brickley et al., 1988; Chen, Harford \& Li, 2007; Cornett et al., 2007; Sahut \& Othmani Gharbi, 2011). Indeed, each type of institutional investors may have various interests that are more or less aligned with those of family shareholders (Sahut \& Othmani Gharbi, 2011), with different implications on the agency relationship between family principals and institutional ownership.

Following the classification suggested or used in these papers, we distinguish between pressure-sensitive and pressure-insensitive institutional investors. On the one hand, institutional investors that have either potential or existing business relations with the firm are labelled pressure-sensitive because they are less willing to contest management decisions in order to protect those relations (e.g., insurance companies and banks). On the other hand, institutional investors that are less subject to pressures from the firm in which they invest are more apt to act as effective monitors (e.g., investment companies and independent investment advisors). This type of investors is labelled pressure-insensitive. Several scholars present evidence that pressure-insensitive institutional investors are better monitors. For instance, it has been found that pressure-sensitive ownership leads to better acquisition decisions (Chen et al., 2007) and greater discipline on executive compensation (Ozkan, 2011). Analysing the relationship between institutional investor ownership and performance for the S\&P100 firms in the 1990s, Cornett et al. (2007) showed that only pressure-insensitive ownership is positively related to operating cash flow returns, thereby confirming that this type of institutional investors are better monitors.

Applied to firms with a family as first shareholder, we argue that the presence of a pressure-insensitive second blockholder is more likely to be associated with greater performance whereas having a pressure-sensitive investor as second main shareholder will enhance the extraction of private benefits from family owners. As pressure-sensitive investors are less inclined to discipline and/or to contest managerial decisions to protect their business relationships with the firm (Brickley et al., 1988), large family owners will have greater latitude to engage in opportunistic or self-serving behaviours. In contrast, pressure-insensitive investors are more likely to efficiently fulfil their monitoring tasks (Cornett et al., 2007) and to confront their points of view with family shareholders (Brickley et al., 1988), so that the firm can take advantage of the contestability among shareholders (Jara-Bertin et al., 2008). 
Moreover, it has been shown that the ability of large family shareholders to extract private benefits is enhanced in countries where legal protection is weak (Maury, 2006). Thus, in such institutional settings, the absence of effective monitors can be detrimental to corporate performance because majority shareholders have greater latitude to develop behaviours that preserve their own interests (Villalonga \& Amit, 2006). Considering that France is a country characterized by a lower degree of legal protection (La Porta et al., 1999; Dahya et al., 2008), and that pressure-insensitive investors are more likely to act as effective monitors than pressure-sensitive owners (Cornett et al., 2007), we propose the following hypotheses:

H2a: Within listed firms with a family as first shareholder, the presence of a pressure-sensitive institutional investor as second blockholder will negatively affect financial performance.

H2b: Within listed firms with a family as first shareholder, the presence of a pressure-insensitive institutional investor as second blockholder will positively affect financial performance.

\section{Research Method}

\subsection{Sample}

We drew our sample from the SBF120 during the period 2002-2011. We restricted ourselves to non-financial and non-real estate firms. Firms that were dropped from the SBF120 after 2002, but that remained publicly traded and continued to operate, remained in the sample because removing these firms would introduce sample selection bias as firm performance is associated with ongoing inclusion in the SBF index (Cornett et al., 2007). After these adjustments, we were left with a sample of 109 firms.

Financial and organizational information was collected using different sources. On the one hand, we gathered information regarding the firms' ownership structures in two steps. First, information related to the main shareholders was hand-collected using annual reports and firms' websites. Second, as ownership structures provided in annual reports are particularly opaque because many companies use control-enhancing mechanisms such as pyramids and holding corporations (Faccio \& Lang, 2002), we complemented these sources of information with the use of business newspapers and stock exchange websites. On the other hand, financial data for each company and year was obtained from the Amadeus database which provides comparable financial information on European public and private companies.

We are conscious that focusing on a single market can be considered as a limitation since our results are not transferable to other contexts, but narrowing the focus on a single country allow us to avoid the weaknesses of multicountry data such as variations in accounting measures and financial reporting standards or the lack of accuracy in the identification of family firms (Sacristan-Navarro et al., 2011a; 2015).

\subsection{Variables}

Dependent variable. In accordance with previous research examining performance in listed family firm, we used a profitability ratio ROA (book value operating profit over book value of total assets) to assess firm performance (e.g. Barontini \& Caprio, 2006; Villalonga \& Amit, 2006; Sraer \& Thesmar, 2007; Kowalewski, Talavera \& Stetsyuk, 2010; Sacristan-Navarro et al., 2011). We choose for an accounting measure of firm performance for two reasons. First, market measures of performance generally reflect the expectations of the firm's prospects in future years while accounting measures are more focused on current performance (Sacristan-Navarro et al., 2011). For instance, Tobin's q of poorly performing firms may be inflated by expectations regarding future events such as a bid premium in a corporate takeover, not ROA. Second, using an accounting measure of performance reduces endogeneity problems in the relationship between institutional ownership and performance (Cornett et al., 2007). For example, as Tobin's q also represents a measure of growth opportunities and as institutional investors may be susceptible to privilege growth stocks, it can be argued that market performance affect institutional ownership. This simultaneity problem is less likely to occur with ROA since this indicator does not reflect expectations concerning growth opportunities.

Independent variables. FSHARFAM is a dummy variable that adopts the value of 1 if a family or an individual is the largest shareholder and holds more than $10 \%$ of the voting rights of the firm, 0 otherwise. Family members were identified through their surnames. This $10 \%$ cutoff is considered as a sufficient threshold for family members to exercise effective control in listed firms (La Porta et al., 1999; Maury, 2006; Sacristan-Navarro et al., 2011). SSHARPRESS-SENS is a dummy variable equaling 1 if the second largest blockholder of the firm is a pressure-sensitive investor that owns more than $5 \%$ of the shares, 0 otherwise. SSHARPRESS-INSENS is a dummy variable equaling 1 if the second largest blockholder of the firm is a pressure-insensitive investor that owns more than $5 \%$ of the shares, 0 otherwise. To determine whether an institutional investor is pressure-sensitive or 
pressure-insensitive, we referred to the classification used in prior studies (Brickley et al., 1988; Almazan, Hartzell \& Starks, 2005; Cornett et al., 2007). As such, we considered bank trust departments and insurance companies as pressure-sensitive investors and investment companies and independent investment advisors (such as pension funds) as pressure-insensitive investors. Following Cornett et al. (2007), we also classified foundations and endowment funds with the pressure-sensitive group in order to be conservative.

Control variables. We included several control variables which are likely to affect firm performance. As family firms are inclined to use control-enhancing mechanisms (Laeven \& Levine, 2008) that negatively affect their performance (Claessens, Djankov \& Lang, 2002), we control for the wedge between voting and cash flow rights held by the largest shareholder. In our study, WEDGE is a dummy variable that equals 1 if a wedge exists between the voting and cash flow rights owned by the largest shareholder (Pindado et al., 2012). As the contest to the control has been shown to positively affect family firm performance (Jara-Bertin et al., 2008), we control for this factor by using a measure of control contestability. CONTEST was measured as the sum of the ownership of the second and third shareholders relative to the ownership of the largest shareholder (Maury \& Pajuste, 2005). We also integrate other control variables which are widely used in the family business literature. GROWTH (firm growth) represents the variation in firm sales related to the previous year. LEV (leverage) is measured as the Book value of total debt/book value of total assets. LSIZE (size) is the natural logarithm of book total assets. We also consider family governance control (FAMGOV); that is, where the firm is family managed and/or family chaired. Finally, we included industry and time dummies to control for time and industry effects.

\subsection{Method}

As it is often argued that the use of different methodological procedures can affect empirical findings regarding the effect of family ownership on performance (Block, Jaskiewicz \& Miller, 2011; Sacristan-Navarro et al., 2011), we ran regressions based on static and dynamic panel data analysis in order to see if both methods lead to identical results. In comparison with cross-sectional analysis, panel data analysis allowed us to control for individual heterogeneity or unobservable individual effects (company effects).

Among static panel data analysis, fixed effect and random effect models are the most frequently employed. While random effect models suppose that companies represent a random sample, fixed affect models assume that firm-specific effects constitute parameters that have to be estimated. To determine whether fixed or random effects models was most suitable for our specifications, Hausman tests were run (Hausman, 1978). Hausman tests performed for each model yielded statistically significant results $\left(\chi^{2}=106.52 * * *\right.$ in Model 1, $\chi^{2}=98.54 * * *$ in Model 2, $\chi^{2}$ $=108.34 * * *$ in Model 3 and $\chi^{2}=94.21 * * *$ in Model 4), suggesting that fixed-effect models were more appropriate than random-effects models.

The problem of static panel data models is that they consider each explanatory variable as exogenous. Thus, this procedure skips a problem that occurs when analysing the relationship between a firm's ownership and performance, namely, endogeneity (Demsetz \& Lehn, 1985; Demsetz \& Villalonga, 2001). To mitigate this problem, we estimated dynamic panel data models by using an instrumental variable estimator developed by Arellano and Bover (1995) and Blundell and Bond (1998), the generalized method of moments (GMM). This method simultaneously estimates a system of two equations, one in levels and one in differences. It also relies on internal instruments to control for endogeneity. In our specifications, explanatory variables are instrumented by their lagged levels in the differenced equation and by their lagged differences in the level equation. The implicit assumption is that differences (levels) in (of) performance in one period, although possibly correlated with contemporaneous differences (levels) in (of) explanatory variables, are uncorrelated with lagged levels (differences) of the latter. Following this method, we use all the right-hand side variables in the models lagged from t- 1 to $t-4$.

To check for the validity of our models, we use the Hansen's (1982) statistic of over-identifying restrictions to test for the absence of correlation between the instruments and the error term. We also tested for the absence of second-order serial correlation in the first-difference residuals. Accordingly, we included the auto(2) test developed by Arellano and Bond (1991). Moreover, we also performed three Wald tests: $F$ for the joint significance of the reported coefficient, $z 1$ for the joint significance of the time dummies, $z 2$ for the joint significance of the industry dummies.

Finally, our dynamic panel data model is as follows:

$$
R O A_{i, t}=\alpha+\beta X_{i, t}+\sum_{t=2002}^{2011} Y_{t}+D U M I N D+\gamma_{i}+u_{i, t}
$$


Where $i$ indexes the firm, $t$ indexes time, $X$ designates the explanatory and control variables, $\sum_{t=2002}^{2011} Y_{t}$ is a set of time dummy variables, DUM IND is a set of industry variables, $\gamma_{i}$ indicates the firm's effect that we consider constant over time, and $u_{i, t}$ is the error term.

\section{Results}

\subsection{Descriptive Statistics}

Table 1 presents the summary statistics (means, standard deviation and correlation matrix) of all the variables included in our regressions. A total of $37 \%$ of the observations corresponds to firms in which the first blockholder is a family while $26 \%$ of the firms are family managed or chaired. We also observe that $13 \%$ and $17 \%$ of the firms have respectively a pressure sensitive or pressure-insensitive institutional investor as second largest blockholder.

The variables' bivariate correlations suggest that having a family as first shareholder is detrimental to firm performance and implies that family members are more likely to be involved in management. Indeed the correlation between FSHARFAM and ROA is significantly negative $(p<.05)$ while the correlation between FSHARFAM and FAMGOV is significantly positive $(p<.01)$. Thus, it appears logical that FAMGOV is negatively related to firm performance $(p<.05)$. Moreover, we notice that having an institutional investor as second blockholder does not seem to impact performance for the whole sample of family and nonfamily firms. Yet, we report that the presence of a family as first blockholder increases the likelihood that control-enhancing mechanisms are used as FSHAR and WEDGE are positively correlated $(p<.10)$. Accordingly, it is not surprising that we observe a negative correlation between FSHARFAM and CONTEST $(p<.05)$. In contrast, the presence of an institutional investor as second blockholder seems to improve the degree of contestability since SSHARPRESS-SENS and SSHARPRESS-INSENS are positively correlated to CONTEST ( $p<.10$ and $p<.05$ respectively).

Although some correlations are important, they do not seem to lead to multicollinearity concerns. When applying Variance Inflation Factors (VIFs), we found that multicollinearity is not a problem as no VIF is above 10 (Kutner, Nachtsheim, Neter \& Li., 2005).

Table 1. Means, standard deviations, and correlations for the sample of family and non-family firms

\begin{tabular}{|c|c|c|c|c|c|c|c|c|c|c|c|c|}
\hline Variable & Mean & S.D. & 1 & 2 & 3 & 4 & 5 & 6 & 7 & 8 & 9 & 10 \\
\hline 1. ROA & 3.974 & 5.756 & 1.00 & & & & & & & & & \\
\hline 2. FSHARFAM & .34 & .172 & $\begin{array}{l}-.13^{* *} \\
(.026)\end{array}$ & 1.00 & & & & & & & & \\
\hline $\begin{array}{l}3 . \\
\text { SSHARPRESS-S }\end{array}$ & .13 & .083 & $\begin{array}{l}-.08 \\
(.113)\end{array}$ & $\begin{array}{l}-.04 \\
(.301)\end{array}$ & 1.00 & & & & & & & \\
\hline ENS & & & & & & & & & & & & \\
\hline $\begin{array}{l}4 . \\
\text { SSHARPRESS-IN }\end{array}$ & .17 & .067 & $\begin{array}{c}.09 \\
(.114)\end{array}$ & $\begin{array}{c}-.05 \\
(.284)\end{array}$ & $\begin{array}{c}.04 \\
(.317)\end{array}$ & 1.00 & & & & & & \\
\hline SENS & & & & & & & & & & & & \\
\hline 5. FAMGOV & .26 & .154 & $\begin{array}{l}-12^{* *} \\
(.039)\end{array}$ & $\begin{array}{l}14^{* * * *} \\
(.000)\end{array}$ & $\begin{array}{l}-.05 \\
(.277)\end{array}$ & $\begin{array}{c}-.04 \\
(.328)\end{array}$ & 1.00 & & & & & \\
\hline 6. WEDGE & .747 & .447 & $\begin{array}{l}-.11^{*} \\
(.064)\end{array}$ & $\begin{array}{l}.10^{*} \\
(.088)\end{array}$ & $\begin{array}{l}-.05 \\
(.246)\end{array}$ & $\begin{array}{c}.08 \\
(.112)\end{array}$ & $\begin{array}{c}11^{*} \\
(.062)\end{array}$ & 1.00 & & & & \\
\hline 7. CONTEST & .738 & .589 & $\begin{array}{c}.09 \\
(.115)\end{array}$ & $\begin{array}{c}-.07 \\
(.145)\end{array}$ & $\begin{array}{l}.10^{*} \\
(.061)\end{array}$ & $\begin{array}{l}.12 * * \\
(.041)\end{array}$ & $\begin{array}{l}-.12 * * \\
(.049)\end{array}$ & $\begin{array}{l}.13^{* *} \\
(.038)\end{array}$ & 1.00 & & & \\
\hline 8. GROWTH & .132 & .762 & $\begin{array}{c}.04 \\
(.294)\end{array}$ & $\begin{array}{l}-.05 \\
(.187)\end{array}$ & $\begin{array}{c}.07 \\
(.203)\end{array}$ & $\begin{array}{c}.08 \\
(.109)\end{array}$ & $\begin{array}{c}-.05 \\
(.193)\end{array}$ & $\begin{array}{c}.02 \\
(.687)\end{array}$ & $\begin{array}{c}.02 \\
(.488)\end{array}$ & 1.00 & & \\
\hline 9. LEV & .624 & .203 & $\begin{array}{c}.03 \\
(.321)\end{array}$ & $\begin{array}{c}-.04 \\
(.268)\end{array}$ & $\begin{array}{c}.09 \\
(.113)\end{array}$ & $\begin{array}{c}.03 \\
(.387)\end{array}$ & $\begin{array}{c}-.06 \\
(.127)\end{array}$ & $\begin{array}{c}-.01 \\
(.734)\end{array}$ & $\begin{array}{l}-.12^{* *} \\
(.021)\end{array}$ & $\begin{array}{c}.05 \\
(.106)\end{array}$ & 1.00 & \\
\hline 10. LSIZE & 9.576 & 2.13 & $\begin{array}{c}-.14 * * * \\
(.000)\end{array}$ & $\begin{array}{c}.06 \\
(.113)\end{array}$ & $\begin{array}{c}.07 \\
(.214)\end{array}$ & $\begin{array}{c}.04 \\
(.279)\end{array}$ & $\begin{array}{c}.02 \\
(.467)\end{array}$ & $\begin{array}{c}.01 \\
(.854)\end{array}$ & $\begin{array}{c}-.01 \\
(.863)\end{array}$ & $\begin{array}{c}.02 \\
(.741)\end{array}$ & $\begin{array}{c}.03 \\
(.381)\end{array}$ & 1.00 \\
\hline
\end{tabular}

$* p \leq .10 .{ }^{* *} p \leq .05 .{ }^{* * *} p \leq .01 . p$ value for each correlation is reported within brackets. 


\subsection{Regression Analyses}

Static panel data analyses are reported in Table 2 . According to model 1, the presence of a family as first blockholder hampers firm performance $(\beta=-20.454, p<.01)$, thereby supporting hypothesis 1 . We also observe that FAMGOV is negatively related to firm performance $(\beta=-15.352, p<.05)$. In model 2 , we try to measure how the combination of the family as first blockholder and institutional investors of different types as second blockholders affects firm performance by replicating our regressions in the subsample of firms in which a family is the first blockholder. The results indicate that the presence of a pressure-sensitive institutional investor as second blockholder has a negative effect on firm performance $(\beta=-4.325, p<.05)$ whereas the opposite is found for pressure-insensitive institutional investors $(\beta=3.147, p<.05)$. These observations support hypotheses $2 \mathrm{a}$ and $2 \mathrm{~b}$.

Table 2. Fixed vs random effects models

\begin{tabular}{lcccc}
\hline Variable & Model 1 & Model 2 & Model 3 & Model 4 \\
& ROA & ROA & ROE & ROE \\
\hline Intercept & $-3.521^{* * *}(.280)$ & $-6.84 * *(.049)$ & $-10.454^{* *}(.019)$ & $-6.325^{*}(.236)$ \\
FSHARFAM & $-21.012 * * *(.009)$ & & $-24.314 * * *(.004)$ & $-3.254 * *(.028)$ \\
SSHARPRESS-SENS & $-6.357(.437)$ & $-4.325 * *(.019)$ & $-5.378(.432)$ & $2.847 * *(.022)$ \\
SSHARPRESS-INSENS & $4.752(.038)$ & $3.147 * *(.012)$ & $5.057(.478)$ & $-4.274 * *(.028)$ \\
FAMGOV & $-15.352^{* *}(.057)$ & $-5.847 * *(.036)$ & $-13.438^{* *}(.047)$ & $1.62(.234)$ \\
WEDGE & $-.582(.673)$ & $-3.89 * *(.024)$ & $3.21(.114)$ & $.71(.692)$ \\
CONTEST & $.917(.441)$ & $.71(.698)$ & $.47(.708)$ & $-1.30(.109)$ \\
LEV & $-1.247(.113)$ & $-1.21(.119)$ & $-1.24(.114)$ & $-.94 * * *(.000)$ \\
LSIZE & $-.98 * * *(.000)$ & $-.92 * * *(.0 .000)$ & $-.99 * * *(.000)$ & $1.23(.205)$ \\
GROWTH & $.104(.602)$ & $.31(.454)$ & $-07(.829)$ & Yes \\
Annual effect & Yes & Yes & Yes & Yes \\
Industry effect & Yes & Yes & Yes & $68.85 * * *$ \\
$F$ & $75.37 * * *$ & $55.46 * * *$ & .1147 & $50.77 * * *$ \\
$R^{2}$ & 0.1389 & .1297 & $108.34 * * *$ & .1045 \\
Hausman & $106.52 * * *$ & $98.54 * * *$ & 370 & $94.21 * * *$
\end{tabular}

$* p \leq .10 . * * p \leq .05 . * * * p \leq .01 . p$ value for each parameter is reported within brackets.

Table 3 reports our dynamic panel data analyses. It is worth mentioning that Hansen tests are significant for each model, thereby supporting the hypothesis of the absence of correlation between the instruments and the error term. Moreover, the results of the auto(2) test developed by Arellano and Bond (1991) also confirm the absence of second-order serial correlation in the first-difference residuals for each regression. $z_{1}$ presents low levels of significance $(p<.10)$ and $z_{2}$ is not significant, thereby suggesting that we have a weak annual effect and no industry effect.

Usually, after treating endogeneity problems, the results show a lower significance of most of the independent variables. This view is supported as we found that the significance of each explanatory variable tend to be weaker in terms of $p$-values. However, the differences in significance remain low as we do not observe important disparities between static and dynamic panel data analyses. Indeed, only FSHARFAM moves from a significance of .01 in static panel data analyses (models 1 and 3) to a significance of .05 in GMM specifications (models 7 and 8). For the other explanatory variables, our results are very similar to those observed in fixed effect models. 
Table 3. GMM models

\begin{tabular}{|c|c|c|c|c|}
\hline Variable & $\begin{array}{c}\text { Model } 5 \\
\text { ROA }\end{array}$ & $\begin{array}{c}\text { Model } 6 \\
\text { ROA }\end{array}$ & $\begin{array}{c}\text { Model } 7 \\
\text { ROE }\end{array}$ & $\begin{array}{c}\text { Model } 8 \\
\text { ROE }\end{array}$ \\
\hline Intercept & $-2.764(.285)$ & $-3.424(.280)$ & $-5.88 *(.068)$ & $-10.22 * *(.028)$ \\
\hline FSHARFAM & $-20.454 * *(.023)$ & & $-19.71 * * *(.028)$ & \\
\hline SSHARPRESS-SENS & $-5.425(1.241)$ & $-4.746 * *(.032)$ & $-6.247(1.325)$ & $-4.874 * *(.046)$ \\
\hline SSHARPRESS-INSENS & 4.784(.897) & $3.897 * *(.029)$ & $5.031(.978)$ & $2.978 * *(.039)$ \\
\hline FAMGOV & $-14.241 * *(.061)$ & $-5.451 * *(.032)$ & $-12.457 * *(.042)$ & $-4.897 * *(.024)$ \\
\hline WEDGE & $-.352(.816)$ & $-.465(.767)$ & $-3.022 * *(.034)$ & $3.077(.123)$ \\
\hline CONTEST & $.767(.491)$ & $.852(.578)$ & $.674(.738)$ & $.424(.760)$ \\
\hline LEV & $-1.383(.103)$ & $-1.257(.114)$ & $-1.192(.122)$ & $-1.201(.124)$ \\
\hline LSIZE & $-.954 * * *(.000)$ & $-.936 * * *(.000)$ & $-.897 * * *(.0 .000)$ & $-.99 * * *(.000)$ \\
\hline GROWTH & $-.081(.643)$ & $.087(.638)$ & $.296(.560)$ & $-05(.888)$ \\
\hline Annual effect & Yes & Yes & Yes & Yes \\
\hline Industry effect & Yes & Yes & Yes & Yes \\
\hline$F$ & $106.20 * * *$ & $109.58 * * *$ & $116.63 * * *$ & $143.38^{* * *}$ \\
\hline$z_{1}$ & $5.21 * *$ & $3.27^{*}$ & $5.51 * *$ & $3.46^{*}$ \\
\hline$z_{2}$ & 1.29 & 1.41 & 1.58 & 1.13 \\
\hline auto(2) & .35 & .95 & .71 & -.22 \\
\hline Hansen & $321.52 * *$ & $334.47 * *$ & $378.37 * *$ & $341.89 * *$ \\
\hline No. of observations & 1090 & 370 & 1090 & 370 \\
\hline
\end{tabular}

$* p \leq .10 .{ }^{* *} p \leq .05 .{ }^{* * *} p \leq .01 . p$ value for each parameter is reported within brackets.

In summary, our results do not show important differences in the significance of the coefficients of the variables. Accordingly, it can be argued that our results are quite robust as they do not vary depending on the methodology. However, we feel that methodological choices can affect the degree of significance of the explanatory variables as we observed that $p$-value slowly decreases when moving from static to dynamic panel data analyses.

As additional robustness check, we ran additional regressions that take into account an alternative measure of performance. Indeed, disparities in research analyzing family firm performance can be explained by the performance indicator used as dependent variable (Martínez, Stöhr \& Quiroga, 2007; Allouche, Amann, Jaussaud \& Kurashina, 2008). Accordingly, we replicated our regressions using another performance measure: ROE, which is defined as net income divided by total equity. While ROA offers a wider perspective of performance, using ROE allowed us to determine whether specific types of ownership were more profitable from the point of view of shareholders. The results obtained with this performance indicator are not significantly different from those found using ROA (see models 3, 4, 7 and 8), thereby confirming the robustness of our findings.

\section{Discussion and Conclusion}

This article examined the performance implications of the combination of large shareholders in listed companies characterized a high ownership concentration in the hand of the family. Our analysis was based on a comprehensive sample of French nonfinancial firms listed on the SBF120 over the period 2002-2011. By focusing on the French stock market, we selected an institutional setting characterized by a lower degree of shareholders' protection (La Porta et al., 1999; Dahya et al., 2008) and intense agency conflicts between majority and minority shareholders (Charlier \& Lambert, 2013). Moreover, as institutional ownership is a dominant force on the French stock exchange (Aglietta, 2008), this context was particularly appropriate to determine how different types of institutional investors alleviate or enhance principal-principal agency conflicts between family and nonfamily shareholders.

Our results offer additional insights regarding the dark side of family ownership on different measures of corporate performance. Indeed, the presence of a family as first shareholder appears to be detrimental to value creation. More specifically, our results suggest that large family blockholders are more inclined to extract private benefits in institutional settings with weaker legal protection (Maury, 2006), thereby confirming that agency problems II are particularly intense in this particular context (Cronqvist \& Nilsson, 2003). Furthermore, it also appears that family involvement in the management and/or the board is negatively related to firm performance. These results tend to confirm prior research that underlined the danger associated with an overwhelmed involvement of the family (Arosa, 
Iturralde \& Maseda, 2010; Jara Bertin et al., 2008; Le Breton-Miller, Miller \& Lester, 2011; Maury \& Pajuste, 2005; Sacristan-Navarro et al., 2015).

However, our findings contradict those of Sraer and Thesmar (2007) who showed that family ownership enhances firm performance in the 1.000 largest French listed firms. Even if differences in the samples, the methods and the time periods employed can explain these inconsistencies, another explanation may lie in the fact that we considered the effect of the family as first shareholder while Sraer and Thesmar (2007) did not stress the importance of the position of the family in the ownership structure. Indeed, these authors defined a firm as a family business when a family is a large blockholder but did not determine if the family was the main blockholder. Accordingly, it could be that the family was not powerful enough to directly extract private benefits (Villalonga \& Amit, 2006) or the create coalitions with other large blockholders at the expense of minority shareholders (Jara Bertin et al., 2008)

Furthermore, our results tend to confirm the findings of several scholars who have reported that the combination of large blockholders significantly affects firm performance (Jara Bertin et al., 2008; Maury \& Pajuste, 2005; Sacristan-Navarro et al., 2015). Especially, we found that the relation between multiple blockholders and value creation depends on the nature of the largest shareholders. In particular, our findings reveal that the combination of the family as first blockholder and a pressure-sensitive institutional investor as second blockholder is negatively related to firm performance while the opposite is found when the second blockholder is a pressure-insensitive institutional investor.

An explanation for these observations could be that pressure-sensitive institutional investors are less inclined to discipline and/or to contest managerial decisions to protect their business relationships with the firm (Brickley et al., 1988; Cornett et al., 2007). Accordingly, they are more likely to form alliances with large family owners who are freer to extract private benefits at the expense of minority shareholders which are less able to contest the control of the coalition formed by large family and nonfamily blockholders. In other words, the combination of the family and a pressure-sensitive institutional investors as first and second largest blockholders is more likely to be detrimental to firm performance as they deprive the organization of an adequate level of contestability among shareholders to avoid opportunistic and self-serving behaviors from family owners. In contrast, the positive influence exerted by the presence of a pressure-insensitive institutional investor as second blockholder could be explained by its greater proclivity to challenge, control and scrutinize family owners' decisions as such shareholder does not have to protect existing business relations with the firm (Cornett et al., 2007). As a consequence, family opportunism could be reduced thanks to the stronger monitoring of family owners (Fernando et al., 2014), thereby leading to positive performance implications.

Our study has both theoretical and practical implications. We underscore three theoretical contributions. First, we confirm the assumption that the conflict between majority and minority shareholders is detrimental to performance in firms with large family ownership operating in institutional contexts where the degree of legal protection is weaker (Maury, 2006). By so doing, we answer to a recent call for a better contextualization of corporate governance research (Pindado et al., 2014). Second, this study stressed the importance of considering the identity of large blockholders to obtain a more fine-grained understanding of firm performance, a topic that needs further development in the literature (Sacristan-Navarro et al., 2011b; 2015). Third, by exploring how the interaction between large family and institutional blockholders creates or destroys value, we add empirical evidence to the recent debate around the role of institutional ownership in the family business context (Fernando et al., 2014).

From a practical point of view, our results can be particularly useful for policymakers as they clearly illustrate that minority shareholders' rights can be altered in institutional settings characterized by a lower degree of investors' protection. Based on that, regulations should facilitate the participation of minority investors in the decision-making process. Moreover, this study can make family owners aware of the necessity to collaborate with nonfamily blockholders that have the characteristics of effective monitors. For instance, family owners should accept to sacrifice a part of their socioemotional wealth to promote balanced ownership structures which exclude investors having business relationships with the firm.

Our study presents some limitations. First, as our article proposed a single-country analysis, our results are note generalizable to other institutional settings. Indeed, we focused on the French market which is characterized by a lower degree of legal protection of shareholders (La Porta et al., 1999; Dahya et al., 2008). As such, the monitoring role of large nonfamily shareholders is more important than in institutional settings where minority investors are better protected. Accordingly, future studies should replicate our research in other countries with greater legal protection. For instance, future research should investigate whether the presence of institutional investors also 
impacts value creation in Anglo-Saxon countries despite the lower prominence of "agency problems II" in these institutional settings (Cronqvist \& Nilsson, 2003).

Second, based on prior research (Brickley et al., 1988; Almazan et al., 2005; Cornett et al., 2007), our study classified institutional owners in two groups: pressure sensitive and pressure-insensitive investors. Although this classification has been validated in the literature, we could obtain additional insights about the effect of institutional ownership by distinguishing each type of institutional investors. As our sample was not large enough to deeply explore the heterogeneity among institutional investors, we provide some reflections that could stimulate future research. For instance, whereas insurance and banks are considered as pressure-sensitive investors, insurance companies can be more focused on long-term value than banks due to the lower restrictive fiduciary standards they have to face (Bushee, 2001). As family firms are often characterized by a long-term investment horizon (Miller \& Le Breton-Miller, 2005), we could expect that insurance companies are less inclined to contest family power because they present similar preferences in terms of investment horizon. Accordingly, insurance companies could constitute less effective monitors, which is likely to enhance the extraction of private benefits by large family owners in institutional settings where minority shareholders' rights are not correctly protected (Maury, 2006).

Finally, this article only took into account the influence of institutional ownership on corporate performance. However, having an ownership stake in the firm is often a necessary but not sufficient condition to ensure effective monitoring through the board of directors (Hanson \& Song, 2000). In this study, institutional investor activism through the board of directors has not been considered due to a lack of available and pertinent data. Therefore, future research should investigate how the presence of institutional investors in the board affects corporate monitoring, and indirectly family firm performance, and how the contest to control by institutional investors and the degree of family control interact together to enhance or inhibit value creation (Pindado et al., 2014; Sacristan-Navarro et al. 2015).

By investigating how different types of large shareholders affect firm performance in a specific institutional context, our study presents evidence that effective monitors are required to avoid the extraction of private benefits from large family owners in countries where legal protection is weak. More specifically, our focus on institutional ownership showed that the presence of institutional investors with lower incentives to contest family power (pressure-sensitive ownership) enhance family opportunism. Based on these results, our study provides a set of directions that, we hope, will guide future research in proposing a more fine-grained analysis of institutional investor activism in family firms operating in different institutional settings.

\section{References}

Aglietta, M. (2008). Investisseurs à long terme et gouvernance d'entreprise. Actes des 6èmes Journées d'Economie Financière, Hammamet, Tunisie.

Aguilera, R. V., \& Crespi-Cladera, R. (2012). Firm family firms: Current debates of corporate governance in family firms. Journal of Family Business Strategy, 3(2), 66-69. http://dx.doi.org/10.1016/j.jfbs.2012.03.006

Allouche, J., Amann, B., Jaussaud, J., \& Kurashina, T. (2008). The impact of family control on the performance and financial characteristics of family versus nonfamily businesses in Japan: A matched-pair investigation. Family Business Review, 21, 315-329. http://dx.doi.org/10.1177/08944865080210040104

Almazan, A., Hartzell, J. C., \& Starks, L. T. (2005). Active institutional shareholders and costs of monitoring: Evidence from executive compensation. Financial Management, 34(4), 5-34. http://dx.doi.org/10.1111/j.1755-053X.2005.tb00116.x

Anderson, R., \& Reeb, D. (2003). Founding family ownership and firm performance: evidence from the S\&P 500. The Journal of Finance, 58(3), 1301-1327. http://dx.doi.org/10.1111/1540-6261.00567

Arellano, M., \& Bond, S. (1991). Some tests of specification for panel data: Monte Carlo evidence and an application to employment equations. The Review of Economic Studies, 58(2), 277-297. http://dx.doi.org/10.2307/2297968

Arellano, M., \& Bover, O. (1995). Another look at the instrumental variable estimation of error-components models. Journal of Econometrics, 68(1), 29-51. http://dx.doi.org/10.1016/0304-4076(94)01642-D

Arosa, B., Iturralde, T., \& Maseda, A. (2010). Ownership structure and firm performance in non-listed firms: Evidence from Spain. Journal of Family Business Strategy, 1(2), 88-96. http://dx.doi.org/10.1016/j.jfbs.2010.03.001 
Barontini, R., \& Caprio, L. (2006). The effect of family control on firm value and performance: Evidence from continental Europe. European Financial Management, 12, 689-723. http://dx.doi.org/10.1111/j.1468-036X.2006.00273.x

Bennett, J. A., Sias, R. W., \& Starks, L. T. (2003). Greener pastures and the impact of dynamic institutional preferences. Review of Financial Studies, 16, 1203-1238. http://dx.doi.org/10.1093/rfs/hhg040

Berle, A. A., \& Means, G. C. (1932). The Modern Corporation and private property. New-York: Macmillan Publishing Co.

Block, H. B., Jaskiewicz, P., \& Miller, D. (2011). Ownership versus management effects on performance in family and founder companies: A Bayesian reconciliation. Journal of Family Business Strategy, 2(4), 232-245. http://dx.doi.org/10.1016/j.jfbs.2011.10.001

Blundell, R., \& Bond, S. (1998). Initial conditions and moment restrictions in dynamic panel data models. Journal of Econometrics, 87(1), 115-143. http://dx.doi.org/10.1016/S0304-4076(98)00009-8

Brickley, J. A., Lease, R. C., \& Smith, C. W. (1988). Ownership structure and voting on antitakeover Amendments. Journal of Financial Economics, 28, 279-305. http://dx.doi.org/10.1016/0304-405x(88)90047-5

Bushee, B. J. (1998). Investors on Myopic R\&D Investment Behavior. The Accounting Review, 73(3), 305-333.

Bushee, B. J. (2001). Do Institutional Investors Prefer Near-Term Earnings over Long-Run Value? Contemporary Accounting Research, 18(2), 207-246. http://dx.doi.org/10.1506/J4GU-BHWH-8HME-LE0X

Charlier, P., \& Lambert, G. (2013). Modes de gouvernance et performances des entreprises familiales françaises en fonction des conflits d'agence. Finance Contrôle Stratégie, 16(2), 1-26. http://dx.doi.org/10.4000/fcs.1314

Chen, X., Harford, J., \& Li, K. (2007). Monitoring: Which institutions matter? Journal of Financial Economics, 86(2), 279-305. http://dx.doi.org/10.1016/j.jfineco.2006.09.005

Claessens, S., Djankov, S., \& Lang, L. (2002). Disentangling the incentive and entrenchment effects of large shareholdings. The Journal of Finance, 57, 2741-2772. http://dx.doi.org/10.1111/1540-6261.00511

Cornett, M. M., Marcus, A. J., Saunders, A., \& Tehranian, H. (2007). The impact of institutional ownership on corporate operating performance. Journal of Banking \& Finance, 31(6), 1771-1794. http://dx.doi.org/10.1016/j.jbankfin.2006.08.006

Croci, E., Gonenc, H., \& Ozkan, N. (2012). CEO compensation, family control, and institutional investors in continental Europe. Journal of Banking \& Finance, 36(12), 3318-3335. http://dx.doi.org/10.1016/j.jbankfin.2012.07.017

Cronqvist, H., \& Nilsson, M. (2003). Agency costs of controlling minority shareholders. Journal of Financial and Quantitative Analysis, 38(4), 695-720. http://dx.doi.org/10.2307/4126740

Dahya, J., Dimitrov, O., \& McConnell, J. (2009). Does board independence matter in companies with a controlling shareholder? Journal of Applied of Corporate Finance, 2, 67-78. http://dx.doi.org/10.1111/j.1745-6622.2009.00217.x

Del Guercio, D., \& Hawkins, J. (1999). The motivation and impact of pension fund activism. Journal of Financial Economics, 52(3), 293-340. http://dx.doi.org/10.1016/S0304-405X(99)00011-2

Demsetz, H., \& Lehn, K. (1985). The structure of corporate ownership: Causes and consequences. The Journal of Political Economy, 93(6), 1155-1177. http://dx.doi.org/10.1086/261354

Demsetz, H., \& Villalonga, B. (2001). Ownership structure and corporate performance. Journal of Corporate Finance, 7(3), 209-233. http://dx.doi.org/10.1016/S0929-1199(01)00020-7

Ensley, M.D., \& Pearson, A.W. (2005). An exploratory comparison of the behavioral dynamics of top management teams in family and nonfamily new ventures: Cohesion, conflict, potency, and consensus. Entrepreneurship Theory and Practice, 29(3), 267-284. http://dx.doi.org/10.1111/j.1540-6520.2005.00082.x

Faccio, M., \& Lang, L. (2002). The ultimate ownership Western European corporations. Journal of Financial Economics, 65, 365-395. http://dx.doi.org/10.1016/S0304-405X(02)00146-0

Fama, E. F., \& Jensen, M. C. (1983). Separation of ownership and control. Journal of Law and Economics, 26(2), 301-325. http://dx.doi.org/10.1086/467037 
Family Business Network International. (2008). FBNet International: Pour les autres pays européens. In L'importance des entreprises familiales en Belgique, Family Business Network, 21 p.

Fernando, G. D., Schneible, R. A., \& Suh, S. (2014). Family firms and institutional investors. Family Business Review, 27(4), 328-345. http://dx.doi.org/10.1177/0894486513481474

Gomez-Mejia, L. R., Hoskisson, R. E., Makri, M., Sirmon, D. G., \& Campbell, J. T. (2011). Innovation and the preservation of socioemotional wealth: the paradox of $R \& D$ investment in family controlled high technology firms. Unpublished paper, Management Department, Texas A\&M University.

Goyer, M. (2006). Varieties of institutional investors and national models of capitalism: The transformation of corporate governance in France and Germany. Politics \& Society, 34(3), 399-430. http://dx.doi.org/10.1177/0032329206290427

Hansen, L. P. (1982). Large sample properties of generalized method of moments estimators. Econometrica: Journal of the Econometric Society, 1029-1054. http://dx.doi.org/10.2307/1912775

Hanson, R. C., \& Song, M. H. (2000). Managerial ownership, board structure, and the division of gains in divestitures. Journal of Corporate Finance, 6(1), 55-70. http://dx.doi.org/10.1016/S0929-1199(99)00013-9

Hausman, J. A. (1978). Specification tests in econometrics. Econometrica: Journal of the Econometric Society, 1251-1271. http://dx.doi.org/10.2307/1913827

IFERA (2003). Family business dominate. Family Business Review, 16(4), 235-239.

Jara-Bertin, M., López-Iturriaga, F. J., \& López-de-Foronda, Ó. (2008). The contest to the control in European family firms: How other shareholders affect firm value. Corporate Governance: An International Review, 16(3), 146-159. http://dx.doi.org/10.1111/j.1467-8683.2008.00677.x

Jensen, M. C., \& Meckling, W. H. (1976). Theory of the Firm: Managerial Behavior, Agency Costs and Ownership Structure. Journal of Financial Economics, 3(4), 305-360. http://dx.doi.org/10.1016/0304-405X(76)90026-X

Kelly, K, Craig, S., \& Dugan, I. (2003, September 18). Grasso Quits NYSE Amid Pay Furor. The Wall Street Journal. Retrieved from http://online.wsj.com/article/0,,SB106384343498608400,00.html

Kowalewski, O., Talavera, O., \& Stetsyuk, I. (2010). Influence of family involvement in management and ownership on firm performance: Evidence from Poland. Family Business Review, 23, 45-59. http://dx.doi.org/10.1177/0894486509355803

Kutner, M. H., Nachtsheim, C. J., Neter, J., \& Li, W. (2005). Applied linear statistical models. New York: McGraw-Hill.

La Porta, R., Lopez-De-Silanes, R., \& Shleifer, A. (1999). Corporate ownership around the world. The Journal of Finance, 54(2), 471-517. http://dx.doi.org/10.1111/0022-1082.00115

Laeven, L., \& Levine, R. (2008). Complex ownership structures and corporate valuations. Review of Financial Studies, 21, 579-604. http://dx.doi.org/10.1093/rfs/hhm068

Le Breton-Miller, I., Miller, D., \& Lester, R.H. (2011). Stewardship or agency: A social embeddedness reconciliation of conduct and performance in public family business. Organization Science, 22(3), 704-721. http://dx.doi.org/10.1287/orsc.1100.0541

Martínez, J. I., Stöhr, B. S., \& Quiroga, B. F. (2007). Family ownership and firm performance: Evidence from public companies in Chile. Family Business Review, 20(2), 83-94. http://dx.doi.org/10.1111/j.1741-6248.2007.00087.x

Maury, B. (2006). Family ownership and firm performance: Evidence from Western European Corporations. Journal of Corporate Finance, 12, 321-341. http://dx.doi.org/10.1016/j.jcorpfin.2005.02.002

Maury, B., \& Pajuste, A. (2005). Multiple large shareholders and firm value. Journal of Banking and Finance, 29, 1813-1834. http://dx.doi.org/10.1016/j.jbankfin.2004.07.002

McConaughy, D. L., Walker, M. C., Henderson Jr, G. V., \& Mishra, C. S. (1998). Founding family controlled firms: Efficiency and value. Review of Financial Economics, 7(1), 1-19. http://dx.doi.org/10.1016/S1058-3300(99)80142-6

McConnell, J. J., \& Servaes, H. (1990). Additional evidence on equity ownership and corporate value. Journal of Financial Economics, 27(2), 595-612. http://dx.doi.org/10.1016/0304-405X(90)90069-C 
Miller, D., \& Le Breton-Miller, I. (2005). Managing for the long run: Lessons in competitive advantage from great family businesses. Harvard Business School Press.

Mínguez-Vera, A., \& Martín-Ugedo, J. F. (2007). Does ownership structure affect value? A panel data analysis for the Spanish market. International Review of Financial Analysis, 16(1), 81-98. http://dx.doi.org/10.1016/j.irfa.2005.10.004

Ozkan, N. (2011). CEO compensation and firm performance: an empirical investigation of UK panel data. European Financial Management, 17(2), 260-285. http://dx.doi.org/10.1111/j.1468-036X.2009.00511.x

Pedersen, T., \& Thomsen, S. (2003). Ownership structure and value of the largest European firms: The importance of owner identity. Journal of Management and Governance, 7(1), 27-55. http://dx.doi.org/10.1023/A:1022480016567

Pindado, J., Requejo, I., \& de la Torre, C. (2008). Does family ownership impact positively on firm value? Empirical evidence from Western Europe. Tendencias en Dirección de Empresas (Working Paper No2). Burgos y Salamanca, Spain: Universidades de Valladolid.

Pindado, J., Requejo, I., \& de la Torre, C. (2012). Do family firms use dividend policy as a governance mechanism? Evidence from the Euro zone. Corporate Governance: An International Review, 20(5), 413-431. http://dx.doi.org/10.1111/j.1467-8683.2012.00921.x

Pindado, J., Requejo, I., \& de la Torre, C. (2014). Family control, expropriation, and investor protection: A panel data analysis of Western European corporations. Journal of Empirical Finance, 27, 58-74. http://dx.doi.org/10.1016/j.jempfin.2013.10.006

Pound., J. (1988). Proxy contests and the efficiency of shareholder oversight. Journal of Financial Economics, 20, 237-265. http://dx.doi.org/10.1016/0304-405X(88)90046-3

Sacristán-Navarro, M., Gómez-Ansón, S., \& Cabeza-García L. (2011a). Family ownership and control, the presence of other large shareholders, and firm performance: Further evidence. Family Business Review, 24, 71-93. http://dx.doi.org/10.1177/0894486510396705

Sacristán-Navarro, M., Gómez-Ansón, S., \& Cabeza-García, L. (2011b). Large shareholders' combinations in family firms: Prevalence and performance effects. Journal of Family Business Strategy, 2(2), 101-112. http://dx.doi.org/10.1016/j.jfbs.2011.03.001

Sacristán-Navarro, M., Gómez-Ansón, S., \& Cabeza-García, L. (2013). Other large shareholders in family firms: Do they monitor? In, Smyrnios, K.; Poutziouris, P.Z. and Goel, S. (Eds.), Handbook of Research on Family Business (pp. 161-183, Second ed.). Cheltenham, U.K.: Edward Elgar.

Sacristán-Navarro, M., Cabeza-García, L., \& Gómez-Ansón, S. (2015). The Company You Keep: The Effect of Other Large Shareholders in Family Firms. Corporate Governance: An International Review, 23(3), 216-233. http://dx.doi.org/10.1111/corg.12107

Sahut, J-M., \& Othmani Gharbi, H. (2011). Influence des actionnaires institutionnels français et étrangers sur la performance financière des firmes. La Revue des Sciences de Gestion, 251, 51-62. http://dx.doi.org/10.3917/rsg.251.0051

Shleifer, A., \& Vishny, R. (1986). Large shareholders and corporate control. Journal of Political Economy, 94, 461-488. http://dx.doi.org/10.1086/261385

Shleifer, A., \& Vishny, R. (1997). A survey of Corporate Governance. The Journal of Finance, 52(2), 737-783. http://dx.doi.org/10.1111/j.1540-6261.1997.tb04820.x

Smith, M. P. (1996). Shareholder activism by institutional investors: Evidence from CalPERS. The Journal of Finance, 51(1), 227-252. http://dx.doi.org/10.1111/j.1540-6261.1996.tb05208.x

Sraer, D., \& Thesmar, D. (2007). Performance and behavior of family firms: Evidence from the French stock market. Journal of the European Economic Association, 5(4), 709-751. http://dx.doi.org/10.1162/JEEA.2007.5.4.709

Villalonga, B., \& Amit, R. (2006). How do family ownership, control and management affect firm value? Journal of Financial Economics, 80(2), 385-417. http://dx.doi.org/10.1016/j.jfineco.2004.12.005

Young, M. N., Peng, M. W., Ahlstrom, D., Bruton, G. D., \& Jiang, Y. (2008). Corporate governance in emerging economies: A review of the principal-principal perspective. Journal of Management Studies, 45(1), 196-220. http://dx.doi.org/10.1111/j.1467-6486.2007.00752.x 